\title{
Tai Khun Buddhism and Ethnic-Religious Identity
}

\author{
Klemens Karlsson
}

Buddhism of today is often described as a global trans-national movement, universally accessible. This claim is made especially by Western Buddhists. Looking more closely into Buddhist traditions, one will recognize that there are several national Sanghas and many differing local traditions. Apart from that the Buddhist tradition is divided by national borders and that most Buddhists are directly tied to a national Sangha, the Buddhist tradition is also divided by local cultural customs and ethnic identification.

The identification of religion and ethnic identity is strong among the majority of ethnic groups in Southeast Asia. Peter Jackson (2002) has pointed out that "Thai identity is founded on the assumed identity that to be Thai is to be Buddhist." The same is true about the Burmese: to be Burmese is to be Buddhist. ${ }^{1}$ Religion and ethnicity are both essential parts of the way people perceive their place in the world. Ethnic and religious belonging have a tendency to merge into each other in such a way that it is nearly impossible to separate them. Consequently, religion often plays an important role as a cultural identity marker. This ethnicreligious identity is strongly expressed in religious visual culture, such as religious buildings, devotional pictures and statues.

Therefore, religious visual culture acts like a kind of emblem of identity. Wherever Buddhism spread throughout the Asian continent it adopted many indigenous cultural manifestations. This adaptation to local customs and visual culture merged the Buddhist tradition with ethnic identity and, as a consequence, it may become an important symbol in conflicts. Therefore, at the same time as Buddhist visual culture was, and still is, a uniting factor, it is also part of a process of enclosing and excluding peoples. This paper will look into the history, myth and cult of the Mahāmuni Buddha image (Maha Myat Muni) standing in the middle of Chiang Tung ${ }^{2}$, the regional capital of the East Shan State of Myanmar, and discuss the ways in which religious visual culture expresses ethnic-religious identity and functions as symbols in conflicts.

\section{The Eastern Shan State and the Ethnic-Religious Conflict}

It is important to remember that the culture and history of the Eastern Shan State is quite different from the rest of the Shan States. From a historical point of view, the Shan people of the Eastern Shan State (i.e., the Tai Khun) have had a long and close relationship to neighbouring Tai peoples in northern Thailand, Sipsongbanna and northern Laos. Since the $13^{\text {th }}$ century, Chiang Tung was attached to the loosely connected state of Lan Na. It consisted of a group of autonomous or semi-autonomous principalities or city-states (muang). These city-states paid tribute to local overlords as well as directly to the Burmese or Siamese.

Buddhism was introduced to Chiang Tung from Chiang Mai in northern Thailand. The Chronicle of Wat Padaeng (Saimong Mangrai 1981) describes in detail the trip a Tai monk (Nanagambhira) took to Lanka in the purpose of establishing a new Buddhist order. After his re-consecration in Lanka, he went to Ayutthya, Sukhothai, Chiang Mai and finally to Chiang Tung and established the Wat Padaeng monastery, which is still standing. Much of traditional Tai Khun Buddhism has continued to flourish, even though the Burmese Thudhamma sect was introduced in the Shan States during the Konbaung period (1752-1819).

The close cultural ties in the Upper Mekong are particularly recognizable when considering visual culture, such as Buddha images and buildings. In Chiang Tung there are

\footnotetext{
${ }^{1}$ There are many non-Buddhist minorities in both Thailand and Myanmar, but that does not prevent most of the peoples to consider themselves part of such an ethnic-religious identity.

${ }^{2}$ Chiang Tung is also transcribed as Kengtung, Kyaingtong, Jengtung and Chieng Tung.
} 
many traditional Tai monasteries (wat) and the Buddha images are of a special Tai Khun style, very similar to that of the Tai Lue in Sipsongbanna and elsewhere. Further, the interior of a Tai Khun monastery is characterized by wall paintings in red and gold and banners (tong) hanging from the inner roof, just as in Tai Lue monasteries. It is obvious that this Tai Khun visual culture is expressing non-Burmese ethnicity and national identity and is therefore regarded as dangerous by the Burmese military government. There is a continuous Burmanization of minority areas as a way to manifest dominance and subordination of ethnic culture and religion. The old Chiang Tung palace was a symbol of Tai Khun independence and intimidated the Burmese rulers, who consequentially destroyed it in the middle of the 1990s. This destruction is an obvious example of Burmanization of minorities.

The military regime's active support of Buddhism is an attempt to achieve political legitimacy just like ancient Burmese rulers. Contemporary Buddhist visual culture made by the Burmese in minority areas is encumbered with symbols of Burmese ethnicity and political power. The Burmese military government has constructed religious buildings and Buddha images all over Myanmar. On a hilltop in Mongla at the border between China and Myanmar, they have constructed a large building called "the Peace Pagoda". Next to this building there is a huge standing Buddha image pointing down to the town. This statue and the stüpa express Burmese ethnic identity and at the same time Burmese sovereignty. The same is true about the huge standing Golden Buddha image at the hilltop above Chiang Tung. This image, with its huge size and its golden appearance, radiates Burmese ethnicity and sovereignty. The Burmese military is building dozens of similar new temples and images around the country, both in central Myanmar as well as in ethnic minority regions. Contemporary Buddhist visual culture made by the Burmese in the Tai cultural area is encumbered with symbols of Burmese ethnicity and political power.

\section{The Mahāmuni Buddha and Ethnic-Religious Identity}

In the middle of Chiang Tung, there is a Buddhist temple hall enclosed by a traffic circle. Inside is a huge, golden Buddha image. The image itself is quite spectacular and made in the 1920s as a copy of the most famous Buddha image in Myanmar. It is a crowned image, seated on a throne and clad in Burmese royal style with cords and regalia crossing its chest. The Mandalay Mahāmuni Buddha is a national treasure believed to be filled with the sacred powers of the Buddha himself. The image is a special site of pilgrimage and is believed to provide protection for the country and the rulers. The Chiang Tung Mahāmuni Buddha image is a copy of this Mandalay image and, as a consequence, represents the rulers in Myanmar.

Juliane Schober (1997) has described the ritual veneration of the Mandalay Mahāmuni Buddha image: The image is treated as if it was alive. Early every morning, a monk washes the face of the image, giving special attention to the eyes. The monk has to climb up into the lap of the image so that he can reach its huge, angular face. The laypeople standing at the base of the image hand various paraphernalia to the monk, who wipes the face with a towel and brushes the teeth with a large toothbrush. The proportions of the Mandalay Mahāmuni

Buddha image are highly distorted because of the thick layers of gold-leaf that cover its base, torso, arms, and shoulders, which is not yet the case of the Chiang Tung image.

The ritual made at the Chiang Tung Mahāmuni Buddha image is a simple variant of the one that takes place every morning in Mandalay. At Chiang Tung, the ritual is only made two or three times every month, with prominent laypeople doing the washing and applying goldleaf to the image. The image is not part of any monastery. Instead, fifty lay families handle and guard the image and the temple hall. Five monks from five important monasteries were invited when I visited the ritual. They recited Buddhist texts and took part of the meal at the end of the ritual. 
It is well-known that visual culture can act as important symbols in conflicts. In Buddhist history, several highly venerated Buddha images have been used as emblems of identity and political power. There are numerous stories about important images of the Buddha and how they have been captured in conflicts and installed in new capitals to legitimize the ruler. The Prabang Buddha in Luang Prabang and the Emerald Buddha in Bangkok are some of the most famous examples of Buddha images expressing ethnicreligious identity during political conflicts. The Mahāmuni Buddha in Mandalay has also been seized in conflicts and is still legitimizing political power, and providing protection for the country and the military rulers. It was originally constructed in Arakan (Rakhine State), the western part of today's Myanmar. It is told that many Burmese kings attacked Arakan with the intention of obtaining the Mahāmuni image. In 1784, after his invasion of Arakan, King Bodawpaya finally took the image to Mandalay. The image is still in Mandalay and is regarded by the Burmese as a national treasure.

The tradition places the construction of the image as far back as the time of the Buddha himself. The Buddha breathed life into the image after it was constructed by Indra (Gutman 2001:29-39). The story is therefore expressing the view that the so-called historical Buddha visited Burma and that the image is a true and exact copy of him. Therefore, the Mahāmuni Buddha is believed to be alive and may act as an adviser to the ruler and thus legitimizes the one that is in possession of the image.

A reasonable interpretation may be that the ritual veneration of the crowned Burmese royal style Buddha in the middle of a Tai cultural area is a culturally manifested communication, establishing a link with the sacred Buddhist history and with the Buddha himself. It also establishes a link with Burmese history and with Burmese ethnicity and political hegemony. Seen from the outside, the Mahāmuni Buddha is therefore an emblem of Burmese identity connected with Burmese hegemony as far back as the time of King Bodawpaya and until today's military government. The image is establishing a structural hierarchical order between Burmese hegemony represented by the Mahāmuni Buddha and ordinary Tai Khun people represented by traditional Tai monasteries and visual culture like Buddha images.

This interpretation may, however, be questioned by the local people. Unlike the images recently constructed by the military government, the Mahāmuni image has not become an ethnic symbol in the long armed conflict between the military government and ethnic minorities. It is therefore important to question the interpretation above and take into consideration some further aspects. By the time of the construction of the image the country was under British rule and each Shan State enjoyed a kind of administrative independence as protectorates under the British. The Shan States were not affected by the anti-British nationalist movement at that time. Chiang Tung had also suffered three Siamese invasions between 1849 and 1854, repulsing them with Burmese and Shan aid. This had as a result an increased Burmese influence in the area (Steinberg, 1978:178-9).

It is also known that the motivation behind the construction of the image in 1920 was not an act of some prominent Burmese person. Instead, the making of the image was commissioned by the chief ruler (saopha) of Chiang Tung, Sao Kawn Kiao Intaleng, together with the abbot of Wat Zaing Ngarm. Officials were sent by the saopha to Mandalay to oversee the casting of the image. In 1921, a copy of the original Mahāmuni image was cast by $\mathrm{U}$ Tit and his workers. Thereafter, the image was brought in pieces to Chiang Tung by boat and bullock cart and installed in a temporary building. In 1926, the image was finally installed in a new building (Wat Phra Sao Luang) in the centre of the town.

There is every reason to believe that the explanation behind the integration of a Burmese Buddha image in Tai Khun culture can be found in the dynamics of religious visual culture. Visual art, objects of everyday use and material culture are important parts of a living 
religious tradition. Beautiful objects attract people and make them feel that they are close to something sacred. Facing a Buddha image is like being in the presence of the Buddha himself. The Mahāmuni image is not regarded as representing Burmese ethnicity and political power by the local people. The people of Chiang Tung have instead incorporated the image into their culture and consider it to be a special image filled with sacred power. This beautiful image with its sacred history makes people feel close to something larger than their immediate environment. Facing the Mahāmuni Buddha is like being part of the life history of the Buddha and being in the presence of the Buddha himself. While religious visual culture can be part of a process of enclosing and excluding peoples, it has also had an enormous influence upon the popularity of Buddhism and crossed the borders of both politics and ethnicity.

\section{References}

Gutman, Pamela. 2001. Burma's Lost Kingdoms: Splendours of Arakan. Bangkok: Orchid Press.

Jackson, Peter A. 2002. Thai Buddhist Identity: Debates on the Traiphuum Phra Ruang. In National identity and its defenders: Thailand today, edited by C. J. Reynolds. Chiang Mai: Silkworm Books.

Saimong Mangrai, Sao. 1981. The Padaeng Chronicle and the Jengtung State Chronicle Translated. Ann Arbor: University of Michigan.

Schober, Juliane. 1997. In the Presence of the Buddha. Ritual Veneration of the Burmese Mahamuni Image. In Sacred Biography in the Buddhist Traditions of South and Southeast Asia, edited by J. Schober. Honolulu: University of Hawai'i Press.

Steinberg, David J., ed. 1987. In Search of Southeast Asia: A Modern History. Honolulu: University of Hawai'i Press. 